\title{
A framework for the assessment of top-down vs bottom-up control of heterotrophic nanoflagellate abundance
}

\author{
Josep M. Gasol \\ Institut de Ciències del Mar, CSIC, Passeig Joan de Borbó s/n, E-08039 Barcelona, Spain
}

\begin{abstract}
A model is presented that allows inferences about the main mode of control of planktonic heterotrophic nanoflagellate (HNF) abundance, control by resources or by predation, from the abundances of bacteria and HNF. The model is built upon the observation that field measurements of HNF abundance at most reach concentrations close to those expected for a system in steady-state (with no variation of bacterial abundance). Field and enclosure data from freshwater and marine systems are used to test its utility by regressing $D_{1}$, the distance between the maximal possible concentration of HNF and the actual concentration, to the abundance of micro- or macrozooplankton. It is concluded that the model may help ascertain the impact of microzooplankton on the components of microbial food webs when data on their abundances are not available, and that it can also be used to generate hypotheses on the degree of influence of sources of carbon other than bacteria on flagellates, and the effect of HNF grazing on bacterial specific growth rates
\end{abstract}

KEY WORDS: Heterotrophic nanoflagellates - Top-down - Bottom-up - Bacteria

\section{INTRODUCTION}

The literature presents ample empirical evidence of good correlations between the abundances of some heterotrophic components of the plankton and the standing stock of primary producers, expressed as chlorophyll a concentration (CHL). Equations that relate trophy with heterotrophic biomass or abundance are common: bacterial abundance seems to increase with increasing CHL in a variety of systems (e.g. Ducklow \& Carlson 1992) and it also seems established that the abundance and biomass of zooplankton are higher in systems with more nutrients and chlorophyll (e.g. Hanson \& Peters 1984, Pace 1986).

In particular, the abundances of heterotrophic nanoprotists [mainly heterotrophic nanoflagellates (HNF) but also small ciliates] have been found to be highly correlated with their source of nutrition: bacteria (BT) and picoplanktonic algae in freshwater (Berninger et al. 1991), as well as in marine plankton (see Sanders et al. 1992 and Table 1). In some cases, however, the relationship between these 2 groups (mainly HNF and BT) has been found to be weak albeit significant (Gasol \& Vaqué 1993), suggesting that factors not directly related to resources could generate important variability in the relationship. Experimental and observational evidence has been collected showing that HNF can be subjected to predatory (top-down) control by ciliates (Weisse 1991), cladocerans (Güde 1989), rotifers (Dolan \& Gallegos 1991), copepods (Roman et al. 1988) and dinoflagellates (Kuparinen \& Bjørnsen 1992) in several different environments. Further, both Sanders et al. (1992) with a modeling approach, and Gasol \& Vaqué (1993) analyzing a large data set, concluded that this top-down effect was more important in relatively more eutrophic than in relatively less eutrophic systems.

The at times weak relationship between HNF and $\mathrm{BT}$ could also be due to the known, but rather unexplored, fact that bacteria are not always the main food item of HNF. Kuosa \& Kivi (1989) have claimed that the standing stocks of HNF cannot always be supported by the available BT biomass and thus have to be supported by other food sources. The feeding of 
HNF on phototrophic picoplankton and nanoplankton, viruses or dissolved organic carbon (Sherr \& Sherr 1992, González \& Suttle 1993, Tranvik et al. 1993), and trophic relationships within the nanoplankton assemblage (Parslow et al. 1986, Wikner \& Hagström 1988), could help explain why the BT-HNF relationship is not always strong.

The aim of this article is to present a qualitative model that may help in establishing hypotheses about the main mode of regulation of HNF abundance in a given system. I first analyze the ecological implications of the published BT-HNF relationships on the basis of empirical observations and some energetic considerations. I then use this information to suggest a framework for the analysis of the top-down vs bottom-up regulation of HNF abundance that sets up limits to the abundance of HNF in nature. Some unpublished and some previously published results from different environments and experimental manipulations will be used to test the usefulness of this qualitative model. I conclude by discussing the weaknesses of the model, and suggesting some implications of the described patterns for the regulation of $\mathrm{BT}$ abundance and production in nature.

\section{GENERALITY OF THE BT-HNF RELATIONSHIP}

Berninger et al. (1991) found empirical evidence of a tight relationship between (log) BT abundance and (log) heterotrophic nanoprotist abundance in a wide range of freshwater environments. In fact, such a relationship had been suggested earlier by several researchers working in marine environments (Table 1), and it was corroborated in further work by Sanders et al. (1992). There are quite striking similarities between the slopes of most of these relationships. Out of 8,6 have slopes not significantly different from each other and 4 have slopes not significantly different from 1 (Table 1). This indicates a rather proportional increase of HNF abundance with increasing BT abundance.

Several other workers, however, did not find good correlations between BT and HNF: Jürgens (1992) with a limited range of BT concentrations; J. M. Gasol, A. Simons \& J. Kalff (unpubl.) and Tzaras \& Pick (1994) in several surveys of Canadian lakes; and McManus \& Fuhrman (1990), van Duyl et al. (1990) and Weinbauer et al. (1993) in marine studies. Gasol \& Vaqué (1993) in a literature compilation found the relationship between BT and HNF abundance to be significant but quite weak. One of the conclusions that could be derived from the data set assembled by Gasol \& Vaqué (1993; see Fig. 1A) was that the relationship between these 2 groups over a range of BT abundances between $10^{5}$ and $3.2 \times 10^{7}$ cells $\mathrm{ml}^{-1}$ could be described as a boundary relationship (Duarte 1991) in which the maximal flagellate concentration attainable for a given BT abundance is approximately described as a linear function of BT abundance (Fig. 1A):

$$
\text { Max. } \log H N F=-2.47+1.07 \log B T
$$

The presence of such an empirical boundary suggests that the maximum attainable HNF abundance level for each level of BT abundance is seldom reached. The next section deals with the question: is there a theoretical basis for such a limit?

\section{MAXIMUM ATTAINABLE HNF ABUNDANCE (MAA)}

To answer this question, I computed the HNF abundance that could be found at each BT abundance level based on the general assumption that HNF consume BT and only BT. I repeated the calculation several

Table 1. Literature relationships between the abundances of bacteria (BT) (or total picoplankton) and heterotrophic nanoflagellates (HNF) (or total heterotrophic nanoplankton)

\begin{tabular}{|c|c|c|c|c|c|c|}
\hline Reference & System(s) & $N$ & $r^{2}$ & Constant $\pm \mathrm{SE}$ & Slope \pm SE & $\mathrm{p}$ \\
\hline Linley et al. (1983) a & Coastal and upwellings & 15 & 0.33 & $-1.74 \pm 1.57$ & $0.67 \pm 0.26$ & 0.020 \\
\hline Sieburth \& Davis (1982) & Gulf Stream & 8 & 0.72 & $-5.09 \pm 2.03$ & $1.34 \pm 1.34^{b . c}$ & 0.008 \\
\hline Sieburth \& Davis (1982) & Sargasso Sea & 37 & 0.33 & $0.03 \pm 0.65$ & $0.45 \pm 0.11$ & $<0.001$ \\
\hline Sherr et al. (1984) & Coastal waters & 26 & 0.52 & $-3.91 \pm 1.38$ & $1.07 \pm 0.21^{b . c}$ & $<0.001$ \\
\hline Davis et al. (1985) & North Atlantic & 39 & 0.61 & $-4.12 \pm 0.96$ & $1.24 \pm 0.16^{b c}$ & $<0.001$ \\
\hline Berninger et al. (1991) & Freshwater & 212 & 0.82 & $-3.53 \pm 0.25$ & $1.12 \pm 0.04^{\mathrm{c}}$ & $<0.001$ \\
\hline Berninger et al. (1991) & Lakes & 121 & 0.65 & $-3.09 \pm 0.47$ & $1.05 \pm 0.07^{b_{1} c}$ & $<0.001$ \\
\hline Sanders et al. (1992) & Various & 600 & 0.50 & $-2.40 \pm 0.23$ & $0.90 \pm 0.04^{c}$ & $<0.001$ \\
\hline \multicolumn{7}{|c|}{$\begin{array}{l}\text { a Data transformed from biomass assuming } 4.35 \mathrm{pg} \mathrm{C} \mathrm{HNF}^{-1} \text { and } 0.00719 \mathrm{pg} \mathrm{C} \mathrm{BT}^{-1} \\
{ }^{\mathrm{b} N o t} \text { significantly different from } 1(\alpha=0.05) \\
{ }^{\mathrm{C}} \text { Not significantly different among them }(\alpha=0.05)\end{array}$} \\
\hline
\end{tabular}


Fig. 1. (A) Empirical observations of heterotrophic nanoflagellate (HNF) abundance at each bacterial (BT) abundance for plankton samples in the data set analyzed by Gasol \& Vaqué (1993) with the boundary line fitted by eye. (B) Comparison of this boundary line with Eq. 6 from Table 3 obtained with the procedures described in Table 2. (C) Sensitivity analysis concerning the theoretical calculations, for procedure number 1 (Table 2), presenting the mean, maximum and minimum HNF concentrations expected at each level of BT abundance (see text for explanation). (D) Data from Berninger et al. (1991) with the boundary line (Eq. 1). The dotted line in (A) and (D) corresponds to the 'mean realized abundance' line described in the text
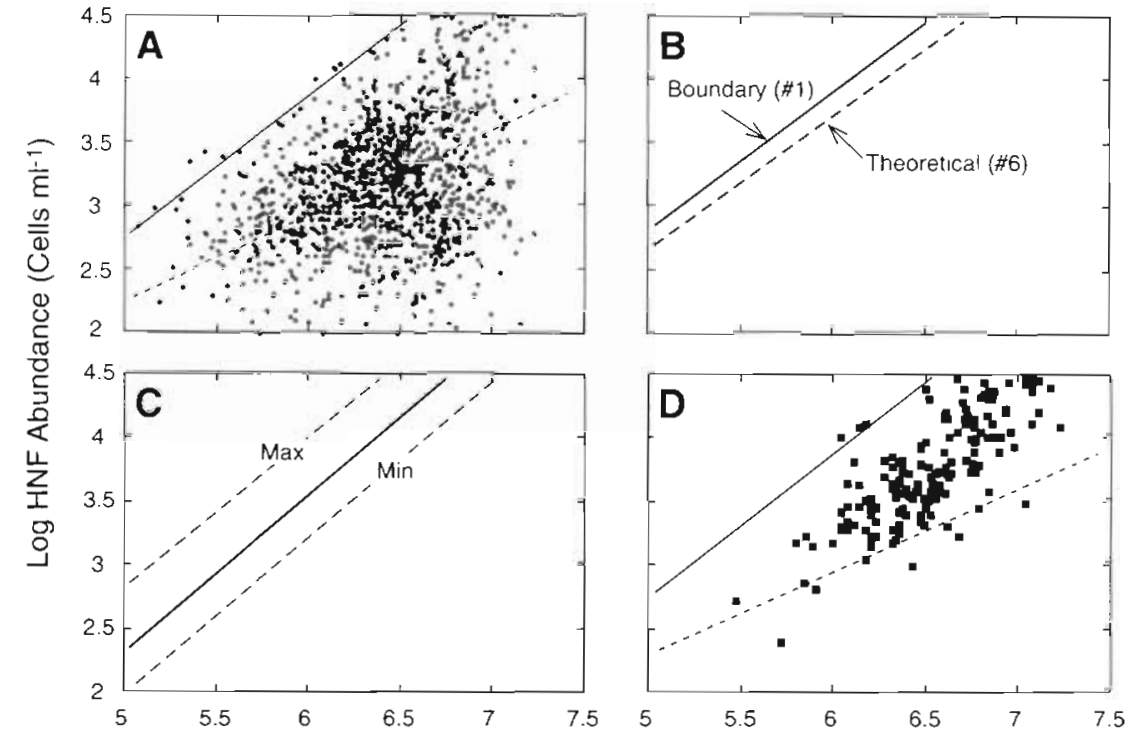

Log Bacterial Abundance (Cells $\mathrm{ml}^{-1}$ ) times making different assumptions, all of them risky, that are summarized in Table 2 , and starting from a gradient of BT abundance. In procedure 1 (P1), BT production was estimated from BT abundance with the empirical tools provided by White et al. (1991). Then, I calculated the HNF carbon that could be sustained by this BT production, without changes in BT abundance. In P2, I used empirical relationships between HNF grazing rates and temperature and BT abundance (Vaqué et al. 1994) to calculate how many flagellates would be needed to completely remove all BT production (BT net growth $=0$ ). In P3, I simply assumed predator biomass to equal prey biomass (which is the prediction of some theoretical models of steady-state phagotrophic food chains; Kerr 1974), and in P4 I assumed all BT production was consumed and converted into HNF growth with a doubling time of $1.5 \mathrm{~d}$ (which is in the higher end of HNF growth rates measured by Weisse 1991). Although the different methods generated different HNF abundances, they were quite close. I then calculated the HNF numbers expected with each equation (Eqs. 2 to 5 in Table 3) for different BT abundances and regressed those values to BT abundance to obtain Eq. 6 (average) in Table 3. This equation is surprisingly close to Eq. 1 (Fig. 1B), the empirical boundary of the data that had been collected by Gasol \& Vaqué (1993, Eq. 1 in Table 3).

Because of the many assumptions involved in these equations, I did a sensitivity analysis by comparing the maximal and minimal estimates obtained when using the upper and lower limits of all the conversion factors needed. For example, for P1, 4 conversion factors are needed (Table 2). For the first one, BT abun- dance to BT production, I took the BT production $95 \%$ prediction limits (computed from the statistics reported in White et al. 1991). The second one assumes how much carbon the HNF biomass needs to maintain itself; Kuosa \& Kivi (1989) used a value of $47.5 \%$ of body carbon $\mathrm{d}^{-1}$. I used 30 and $60 \%$. Volumetric gross growth efficiencies have been found to range between 18 and $75 \%$ (Choi \& Peters 1992, see also Table 7.5 in Caron \& Goldman 1990). The third conversion factor requires mean flagellate size. I used the mean standard error of all the measurements done in 1 summer in 19 Canadian lakes sampled in different months (Gasol et al. unpubl.). The fourth conversion factor (carbon to volume) was left untouched. The minimal, mean and maximal predictions are shown in Fig. 1C. P4 was also repeated assuming flagellate doubling times ranging from 1 to 2 . Even with the high variation associated with each of these calculations, the fact that they point to the same kind of trend, and that they seem to coincide with the empirical observations (Fig. 1A) indicate that my average 'maximum attainable abundance' line (henceforth MAA; Fig. 2) is a real feature of the relationship between predator and prey abundance. The line is a predator zero isocline in a Lotka-Volterra model in which larger populations of predators require larger populations of prey to maintain themselves (p. 344 in Begon et al. 1990). For all points on the line, all BT production is removed by HNF given the aforementioned assumptions. At any HNF abundance higher than that predicted by the MAA line, HNF predation would remove more BT cells than produced, and would reduce BT abundance. 


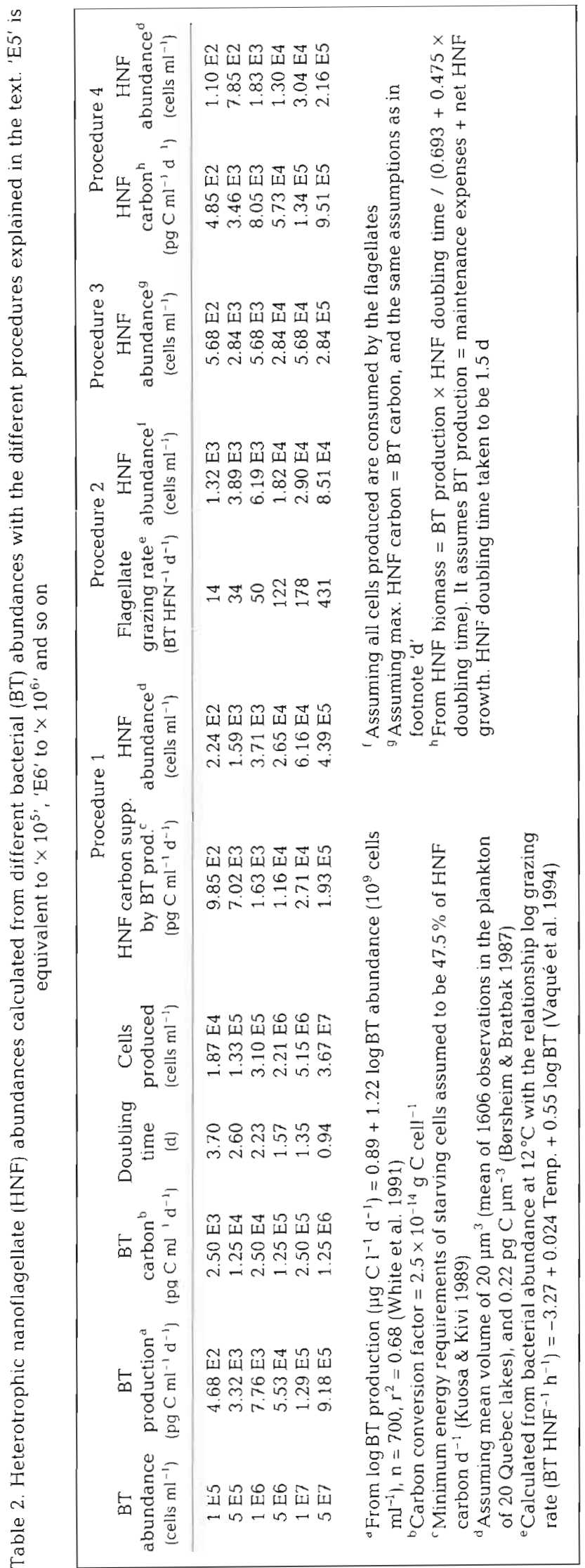

Table 3. Comparison of the parameters of several equations predicting maximum HNF abundance at each BT abundance level. Eqs. (2) to (5) are calculated (Table 2), the others are empirical. All equations relate log HNF abundance (dependent variable) to $\log \mathrm{BT}$ abundance (independent variable). The boundary equations are fitted approximately

\begin{tabular}{|lccll|}
\hline Relationship & Intercept & Slope & Source & Eq. \\
\hline Boundary & -2.47 & 1.07 & $\begin{array}{l}\text { Data in Gasol \& } \\
\text { Vaqué (1993) }\end{array}$ & $(1)$ \\
Calculated P1 & -3.89 & 1.26 & Table 2 & $(2)$ \\
Calculated P2 & -0.31 & 0.69 & Table 2 & $(3)$ \\
Calculated P3 & -2.36 & 1.03 & Table 2 & $(4)$ \\
Calculated P4 & -4.28 & 1.26 & Table 2 & $(5)$ \\
Average & -2.55 & 1.04 & Average of & Eqs. (2) to (5) \\
& & & & \\
\hline
\end{tabular}

The empirical line that Berninger et al. (1991) computed had a slope that is not significantly different from that of the MAA line (Tables $1 \& 3$ ). The intercept was quite smaller although the standard error of the estimate (0.3) implies that the confidence bands for the estimate would include the MAA line (Fig. 1D). Most of the points in the Berninger et al. (1991) line fall below the MAA line, but quite close to it. In the light of the present model this indicates that in most of the situations that these authors sampled, protozoans were using most of the BT production and thus were regulating $\mathrm{BT}$ abundance.

\section{MEAN REALIZED ABUNDANCE (MRA)}

When the abundances of BT and flagellates were averaged per study in a literature survey (Gasol \& Vaqué 1993) or per lake in field data (Gasol et al. unpubl.), mean HNF abundance and mean BT abundance were significantly correlated (Table 4). The

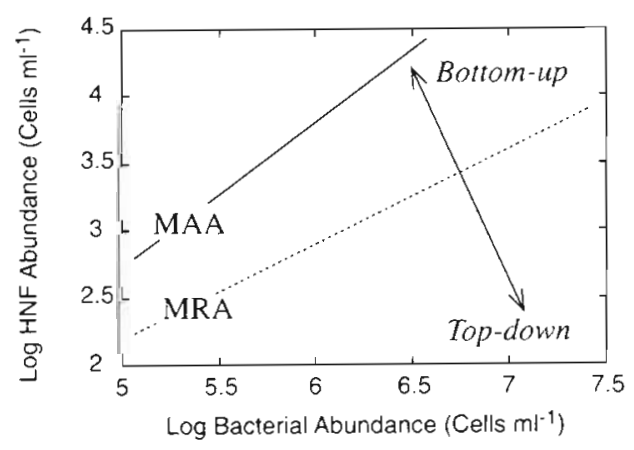

Fig. 2. Framework for the analysis of the mechanisms of control of the abundances of HNF, with the MAA (maximum attainable abundance) and MRA (mean realized abundance) lines, and indication of the position of the points where the mechanism of control of HNF abundance is mainly top-down and bottom-up 
Table 4. Characteristics of the relationship between mean bacterial abundance and mean flagellate abundance for different data sets. Neither the slopes nor the intercepts are significantly different among them

\begin{tabular}{|c|c|c|c|c|c|}
\hline Data set & $N$ & Slope \pm SE & Intercept $\pm \mathrm{SE}$ & Source & $\mathrm{Eq}$ \\
\hline Lakes & 51 & $0.74 \pm 0.11$ & $-1.57 \pm 0.72$ & Gasol \& Vaqué (1993) & (7) \\
\hline Marine & 41 & $0.79 \pm 0.19$ & $-1.67 \pm 1.19$ & Gasol \& Vaqué (1993) & (8) \\
\hline Quebec lakes & 18 & $0.67 \pm 0.15$ & $-1.12 \pm 0.95$ & Gasol et al. (unpubl.) & (9) \\
\hline Other lakes ${ }^{a}$ & 29 & $0.74 \pm 0.17$ & $-1.56 \pm 1.12$ & Gasol et al (unpubl.) & $(10)$ \\
\hline
\end{tabular}

slopes of these equations were, however, significantly lower than 1 (except for the marine data). They predicted that an increase in BT abundance would not be followed by a proportional increase in HNF abundance.

Once the seasonal variability (which includes periods of top-down and periods of bottom-up regulation; Weisse 1991, Gasol et al. unpubl.) has been integrated, the average line (presented in Table 4) could be interpreted as a 'mean realized abundance' (MRA; Fig. 2) line, that averages the effect of both types of regulation throughout the year. The fact that the equations obtained with the lake data, and also the means for marine studies, have very similar slopes (Table 4) suggests that whatever the top-down and bottom-up mechanisms are, they operate similarly in both kinds of systems. This regularity gives confidence to the contention that the MRA line can be taken as a reference line to interpret the relative importance of bottom-up or top-down factors in regulating HNF abundance.

\section{THE QUALITATIVE MODEL}

I suggest a way to plot the individual concentrations of BT and HNF that may shed light on the main mechanism of regulation of HNF abundance (Fig. 2). Simultaneous observations of BT and HNF abundance are plotted in a bivariate space that includes the MAA line (Eq. 1 in Table 3) and the MRA line (Eq. 1 in Table 4). Points close to the MAA line would indicate bottom-up control of HNF abundance, while points below MRA would indicate predatory control of the flagellates. When there is clear top-down (zooplankton) control, the points would lie far below the MRA line. An extreme observation in this top-down regulation of HNF by zooplankton was observed in Lake Cisó, NE Catalonia, Spain, in September 1992. Coincident with an invasion by Daphnia pulex (more than 700 ind. $1^{-1}$ ), HNF concentration was below 50 cells $\mathrm{ml}^{-1}$ while BT were at ca $3 \times 10^{6}$ cells $\mathrm{ml}^{-1}$ (Jürgens et al. 1994). In this extreme case, the point corresponding to this situation is placed far below the MAA line (in fact, off the limits of Fig. 2). When $D$. pulex were filtered out, and HNF were allowed free growth, BT abundance in equilibrium was near $1.8 \times$ $10^{6}$ cells $\mathrm{ml}^{-1}$, and HNF at 8.0 to $10.0 \times 10^{3}$ cells $\mathrm{ml}^{-1}$. Then, the point was located very close to the MAA line.

A consequence of this model is that the distance from the actual HNF concentration to the maximum predicted by Eq. (8) for the observed BT concentration (magnitude that I call $D$ ) should be correlated to the abundance of HNF predators (if $\mathrm{HNF}$ are being depressed by the predators). Thus, from the easily available abundances of $\mathrm{BT}$ and HNF, we can infer the main mode of control of flagellate abundance, and, in case we have abundance data for other organisms, whether they are responsible for the top-down control of the HNF. Next, I test this hypothesis and the utility of the proposed model with literature data from marine and freshwater habitats.

\section{TESTING THE MODEL}

Two examples from freshwater will clarify the utility of the model. In Lake Magog, Quebec, Canada, in 1990 (data from Gasol et al. unpubl.), the point sampled in May (right after the spring phytoplankton bloom) fell close to the MAA line (Fig. 3A). The point in June (clearwater phase) fell well below the MRA line, while the other points fell around the MRA line. For Lake Magog, HNF abundance was negatively correlated to Daphnia spp. abundance $(n=5, r=-0.97, p=0.008$; Fig. 3B). The distance between the theoretical (Eq. 8) HNF abundance and the actual abundance $(D$. computed as the ratio of untransformed abundances) was positively correlated with the abundance of Daphnja spp. $(n=5$, $r=0.84, p=0.07$ ). Similarly, in Lake Constance, Central Europe, in 1985 and 1987 (data from Güde 1988, and Jürgens \& Güde 1991), the simultaneous observations of HNF abundance and BT abundance include values close to the MAA line and values far down the line (Fig. 3C). In fact, the abundance of Daphnia spp. can be negatively correlated to that of HNF $(r=-0.74, p<$ 0.0005; Fig. 3D). Thus, the points closer to the MAA line have the lower abundances of Daphnia spp., while those points below the MRA line have higher Daphnia spp. 

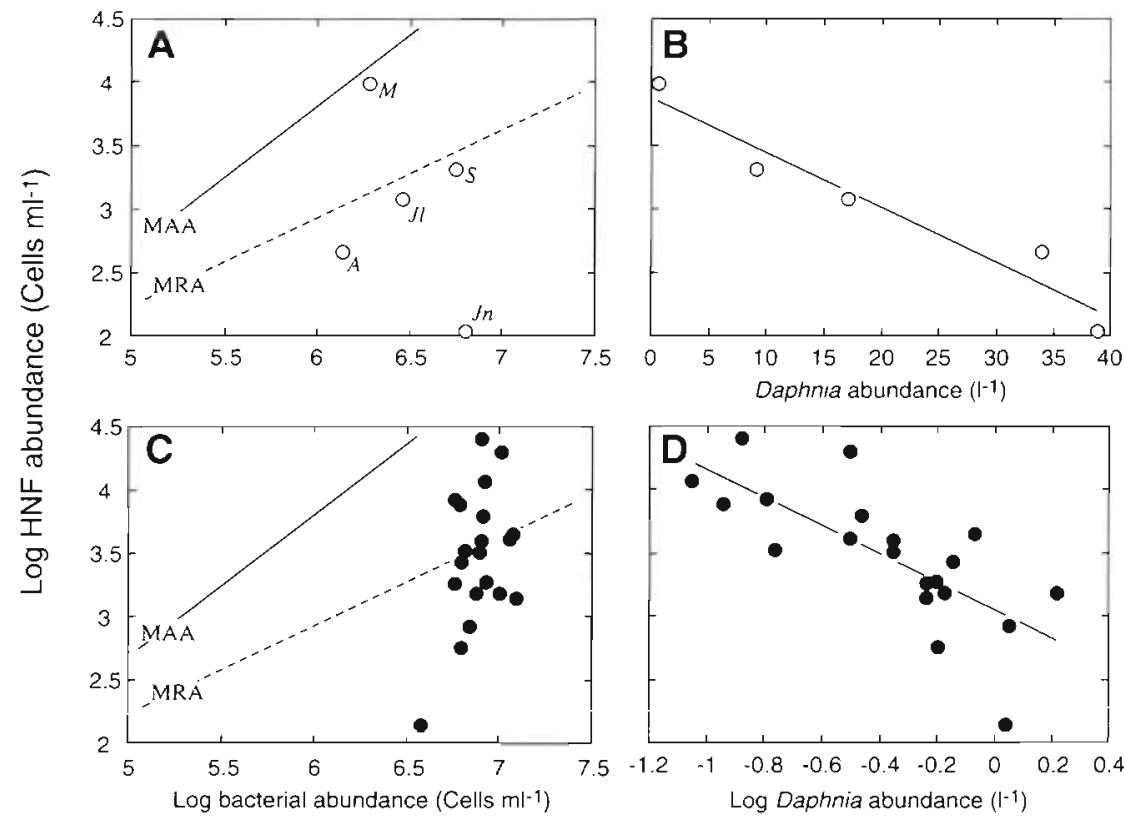

Fig. 3. (A) Simultaneous observations of BT and HNF abundance in Lake Magog, Quebec, Canada (Gasol et al. unpubl.) placed in the framework of Fig. 2. M: May; Jn: June; Jl: Julyi $A$ : August $S$ : September. (B) Corresponding Daphnia spp. concentrations and HNF abundances in Lake Magog. (C) Simultaneous observations of BT and HNF abundance in Lake Constance, Central Europe (Güde 1988, Jürgens \& Güde 1991) with MAA and MRA lines. (D) Daphnia spp. concentrations and HNF abundances in Lake Constance. Note that the scale is logarithmic

abundances. The distance $D$ is positively correlated to the abundance of $D$. pulex $(n=20, r=0.80, p<0.0005)$. This distance is, thus, a good representation of the topdown impact on HNF in these lakes. In all cases, the value of $D$ reflected the top-down effect on $H N F$, and was correlated to the HNF predators in those cases where we knew which those predators were. In fact, the computation of $D$, even without knowledge of the zooplankton community composition, allows the assessment of the top-down impact on HNF.
Data sets similar to those of freshwater are not available for marine environments. Simultaneous observations of the abundance of BT, HNF and HNF predators are not very common. In some cases ciliate abundance is reported, but not all ciliates will prey upon HNF, as some are known to be mainly bacterivorous. For example, in the data set of Andersen \& Sørensen (1986), in which well-coupled predator-prey oscillations between ciliates, HNF and BT are reported, BT and HNF were not correlated (Fig, 4A) and ciliates were not correlated

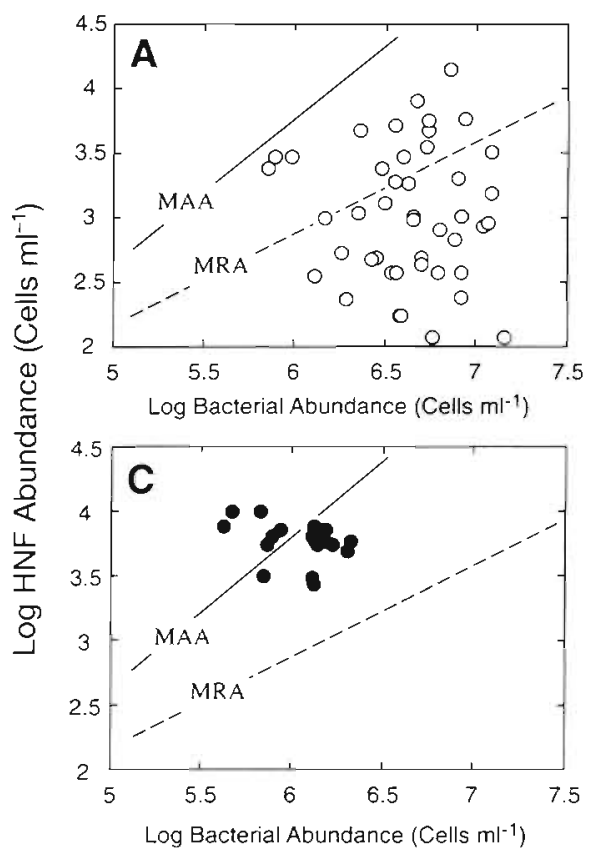

Fig. 4. (A) Simultaneous observations of $B T$ and HNF abundance in the Limfjorden, Denmark (Andersen \& Sorensen 1986), with MAA and MRA lines. (B) Relationship between ciliate abundance and the difference between the maximum and the actual HNF abundance. This difference $(D)$ is computed as the ratio of the nontransformed abundances or the difference between the log-transformed abundances. (C) Simultaneous observations of BT and HNF abundance in the Rhode River Estuary, Maryland, USA (Dolan \& Gallegos 1991) with the MAA and MRA lines. (D) Relationship between Synchaeta (sp. 2) abundance and the ratio $D$ 
with HNF. However, even in such case, there was a significant positive correlation between ciliate abundance and the distance $D$ (Fig. $4 \mathrm{~B}, \mathrm{n}=46, \mathrm{r}=0.42, \mathrm{p}=0.004$ ). The same pattern was detected in the data set of Barcina et al. (1992), also from a coastal ocean area, in which the distance was again correlated to the abundance of ciliates $(n=9, r=0.74, p=0.02)$. In the data set presented by Dolan \& Gallegos (1991) there was an apparent coupling between the abundance of BT, HNF and the abundance of 1 Synchaeta species. In fact, some of the HNF numbers reported in this study were well above the MAA line (Fig. 4C). Again, the distance $D$ was positively correlated to the abundance of the rotifer, when the rotifer was present $(n=18, r=0.66, p=0.003$; Fig. $4 D)$.

Further evidence of the utility of the qualitative model is presented in Fig. 5A. I selected some freshwater systems for which information was available, and computed the average ( \pm standard error) BT and HNF concentration, and plotted those averages in the framework of Fig. 2. Interestingly, Lake Ontario (North America) appeared above the MRA line, while Rimov Reservoir (Czech Republic), Lake Bowker (Quebec, Canada), and Lakes Tuesday and Paul (Michigan, USA) were placed well below that line. Lake Ontario has low concentrations of a small daphnid (Daphnia retrocurva, Pick \& Hamilton 1994) and the top-down impact on HNF is believed to be low. During certain years, large daphnids have dominated the planktonic community of Rimov Reservoir and a linear food chain composed of BT, HNF and Daphnia spp. was proposed for such a system (Simek et al. 1990). Similarly, oligotrophic Lake Bowker has a zooplankton assemblage dominated by a large Daphnia species (Gasol et al. unpubl.). In Lakes Tuesday and Paul, most of the grazing losses of BT were due to cladocerans (Vaqué \& Pace 1992). One would thus expect cladocerans, and specially Daphnia spp, to equally affect HNF abundances as the size range of the protozoans is well within those usually exploited by these organisms. Finally, Lake Constance appears on the MRA line, but we have already seen that the dispersion of points around this line (Fig. 3C) was negatively correlated to the abundance of Daphnia spp. (Fig. 3D).

Similarly, metalimnetic HNF abundances in Lake Vechten (The Netherlands) were in general higher, relative to $\mathrm{BT}$ abundance, than those of the epi- or hypolimnion (Fig. 5B). Bloem et al. (1989) suggested that this was due to a lack of efficient predation on the HNF in the metalimnion. In effect, the points lie above the MRA line and closer to the MAA line than those of other parts of the lake. A similar analysis with Lake Biwa (Japan) epi- and metalimnetic data (from Nagata 1988) confirms the pattern as does the vertical distribution of BT and HNF in Lake Nakanuma (Japan) (see Fig. 5 in Watanabe 1992).
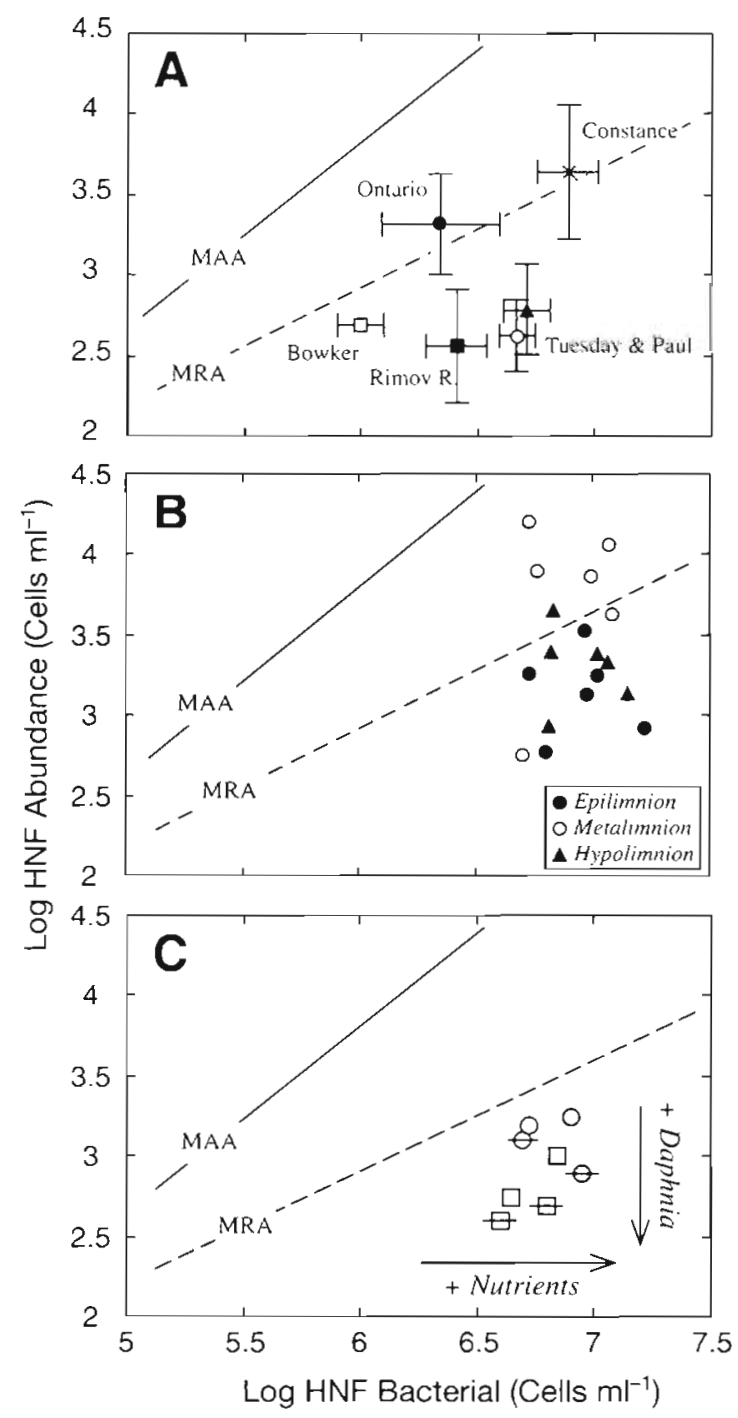

Fig. 5. (A) Mean and standard error of the abundances of HNF and BT in several lakes, and their relationship to the MAA and MRA lines. Data from Pick \& Caron (1987; Lake Ontario, North America); Jürgens \& Güde (1991; Lake Constance, Central Europe); Vaqué \& Pace (1992; Lakes Tuesday and Paul, Michigan, USA); Simek et al. (1990; Řimov Reservoir, Czech Republic); and Gasol et al. (unpubl.; Lake Bowker, Quebec, Canada). (B) Abundances of HNF and BT in the meta-, epi- and hypolimnion of Lake Vechten, The Netherlands (data from Bloem et al. 1989). (C) Relative position of the abundances of HNF and BT in the experiments reported by Pace \& Funke (1991) for Paul Lake $(\square, \square)$ and Peter Lake $(0,0)$. Open symbols: enclosure did not receive nutrient additions; shaded symbols: enclosure did. Crossed symbols: enclosure received Daphnia spp. additions; noncrossed: enclosure did not

Finally, I tested the performance of the qualitative method with the data from enclosure experiments performed in Lakes Peter and Paul (Michigan, USA) by Pace \& Funke (1991). The addition of nutrients in both lakes increased the abundance of BT more than the 
abundances of HNF (Fig. 5C). Similarly, Daphnia spp. additions (simulating a cascading top-down effect) depressed HNF abundances more than they affected BT abundances. The top-down effect of Daphnia spp. was more important in the enclosures with nutrient additions than in those without added nutrients.

\section{ASSUMPTIONS AND IMPLICATIONS}

There are 2 main assumptions of the model that are not questioned during this exercise. First, the model assumes HNF to feed only on BT. We now know that this is not completely true as HNF may use picoplanktonic algae (e.g. Sherr \& Sherr 1992), dissolved organic carbon (Sherr 1988, Tranvik et al. 1993), viruses (González \& Suttle 1993) and there may be trophic relationships within the nanoflagellate assemblage (Parslow et al. 1986, Wikner \& Hagström 1988). However, the portion of HNF carbon demand that is met by these trophic relationships has not been evaluated. Hagström et al. (1988) and Kuosa (1991) calculated that picoalgae were a very relevant food source for HNF when they were abundant, while González \& Suttle (1993) found viruses to be a not very important fraction of HNF resources. Even if the model presented here does not address this question, it can identify some situations where we would expect those $C$ sources to be important. In Fig. 4C, for example, some HNF abundances in the Rhode River (Maryland, USA) estuary were placed above the MAA line. That could suggest that HNF abundances in that system were controlled by bottom-up factors other than BT abundance.

Secondly, HNF in the model are assumed to respond in a way proportional to BT abundance while we know that there is a preferential use of larger BT (Andersson et al. 1986, González et al. 1990, Simek \& Chrzanowski 1992), and even cells in division (Sherr et al. 1992), by HNF. However, without a proper knowledge of the factors that regulate BT size and aggregation in situ there is little more we can do other than recognize the pitfall or, as Jürgens (1992) did, analyze the relationship between HNF and those BT of a certain size only. In any case, as the model that we present is only qualitative, not quantitative, it can be used to get indications of the modes of HNF abundance control, and proper experiments or measurements can be designed afterwards.

Consideration of the spread of simultaneous observations of $\mathrm{BT}$ and HNF abundance in the framework of the model proposed (Fig. 1A, D) confirms the observation that resource dependence of HNF abundance is common in the most oligotrophic situations, and topdown control is more common in the nutrient-rich systems (Hobbie \& Cole 1984, Sanders et al. 1992, Gasol \& Vaqué 1993). The values for oligotrophic sys- tems are closer to the MAA line. Dominant bottom-up control of HNF in the oligotrophic sites would imply grazing control of $\mathrm{BT}$ in these sites or a significant use of resources other than BT by HNF in these environments. Predominant top-down control of HNF in the eutrophic environments would indicate that BT may not be grazer-controlled by HNF in the richer systems (although viruses could have an important role in 'bloom' situations; Thingstad et al. 1993). This pattern agrees with the model proposed by McQueen et al. (1986) if we assume BT to be the producers and HNF the consumers. McQueen et al.'s (1986) model predicts that the effect of primary consumers (HNF) on producers (BT) should be stronger in oligotrophy and, for the producers (BT), increasing productivity should increase biomass and decrease the impact of the consumers (HNF). The implication for BT is that it is only in oligotrophy that they may be tightly coupled to protozoan abundance. In fact, such a tight control of 'producers' abundance has been hypothesized for the control of algal biomass in the most oligotrophic environments (Agustí et al. 1992). Tight coupling among the different components of the microbial food web has been found in oligotrophic coastal (Rassoulzadegan \& Sheldon 1986, Wikner \& Hagström 1988) and open ocean environments (Weisse 1989, Weisse \& ScheffelMöser 1991).

There is disagreement among researchers on whether nutrients or grazing regulate BT production (Riemann 1985, Roman et al. 1988, Wright 1988, Billen et al. 1990). In fact, grazing rates are usually close in magnitude to BT production and when both rates are plotted in the same graph, the points gather around the 1:1 line (Sanders et al. 1989, 1992). It has been argued that it is the grazing removal of BT that would be balanced by net increase in BT (Wright 1988) and by total BT activity (Sherr et al. 1988), not the other way around. If that were true, then BT would produce more when they are top-down controlled by HNF, i.e. when HNF are bottom-up controlled. I used Fig. 2 to test this hypothesis with the data set compiled by Vaqué et al. (1994). This data set was composed of literature data from freshwater and marine environments with simultaneous observations on HNF and BT abundance and BT production. The prediction was that the closer a point is to the MAA line in Fig. 2 (lower $D$ ), the more HNF would top-down control BT and thus BT production would be higher. BT production would be lower the further away from the MAA line (higher $D$ ). In this data set, $D$ was found to be negatively correlated to the $(\log )$ BT specific growth rate $(\mathrm{n}=164$, Pearson $r=-0.37, p<0.00005$ ), suggesting that, indeed, BT more subject to predation (because HNF were more resource-controlled) produced more than BT less subject to predation (because HNF were controlled by 
predators). Sherr et al. (1992) found evidence of a lack of effect of grazing on BT on BT growth rates. However, as the authors themselves stated, their experiments were not designed to investigate such an effect. In any case, the magnitude of $D$ has some potential for use not only in assessing the top-down impact on HNF abundance, but also in testing other hypotheses related to the factors controlling BT abundance and production in nature.

\section{CONCLUSION}

The qualitative model presented (Fig. 2) allows assessment of the main mode of control of HNF abundance in planktonic systems. The fact that different situations (in terms of resource vs predation control of HNF abundance) can be identified using this framework supports its potential for analysis of other data, specially when the abundances of microzooplankton are not available. The model may help in the interpretation of the already published data and relationships between pico- and nanoplankton by identifying the likely limits of those abundances.

Acknowledgements. I thank the authors whose data I used to elaborate this article for publishing them in a usable form, and C. Pedrós-Alió, D. Vaqué, C. Marrasé and several reviewers for offering helpful criticism. This work was supported by the research project DGICYT PB91-075.

\section{LITERATURE CITED}

Agustí, S., Duarte, C. M., Canfield, D. E. Jr (1992). Selfregulation, bottom-up, and top-down control of phytoplankton communities: a reply to the comment by Kamenir. Limnol. Oceanogr. 37: 683-687

Andersen, P., Sørensen, H. M. (1986). Population dynamics and trophic coupling in pelagic microorganisms in eutrophic coastal waters. Mar. Ecol. Prog. Ser. 33: 99-109

Andersson, A., Larsson, U., Hagström, A. (1986). Size-selective grazing by a microflagellate on pelagic bacteria. Mar. Ecol. Prog. Ser. 33: 51-57

Barcina, I., Ayo, B., Unanue, M., Egea, L., Iriberri, J. (1992). Comparison of rates of flagellate bacterivory and bacterial production in a marine coastal system. Appl. environ. Microbiol. 58: 3850-3856

Begon, M., Harper, J. L., Townsend, C. R. (1990). Ecology: individuals, populations and ecosystems, 2nd edn. Blackwell Sci. Publ., Cambridge

Berninger, U.-G., Finlay, B. J., Kuuppo-Leinikki, P. (1991). Protozoan control of bacterial abundances in freshwater. Limnol. Oceanogr. 36: 139-147

Billen, G., Servais, P., Becquevort, S. (1990). Dynamics of bacterioplankton in oligotrophic and eutrophic aquatic environments: bottom-up or top-down control? Hydrobiologia 207: $37-42$

Bloem, J., Ellenbroek, F. M., Bär-Gilissen, M.-J., Cappenberg, T E. (1989). Protozoan grazing and bacterial production in stratified Lake Vechten estimated with fluorescently labeled bacteria and by thymidine incorporation. Appl. environ. Microbiol. 55: 1787-1795
Borsheim, K. Y., Bratbak, G. (1987). Cell volume to cell carbon conversion factors for a bacterivorous Monas sp. enriched from seawater. Mar. Ecol. Prog. Ser. 36: 171-175

Caron, D. A., Goldman, J. C. (1990). Protozoan nutrient regeneration. In: Capriulo, G. M. (ed.) Ecology of marine protozoa. Oxford University Press, New York, p. 283-306

Choi, J. W. Peters, F. (1992). Effects of temperature on two psychrophilic ecotypes of a heterotrophic nanoflagellate, Paraphysomonas imperforata. Appl. environ. Microbiol. 58: $593-599$

Davis, P. G., Caron, D. A., Johnson, P. W., Sieburth, J. MCN. (1985). Phototrophic and apochlorotic components of picoplankton and nanoplankton in the North Atlantic: geographic, vertical, seasonal and diel distributions. Mar. Ecol. Prog. Ser. 21: 15-26

Dolan, J. R., Gallegos, C. R. (1991). Trophic coupling of rotifers, microflagellates, and bacteria during fall months in the Rhode River Estuary. Mar. Ecol. Prog. Ser. 77: 147-156

Duarte, C. M. (1991). Variance and the description of nature. In: Cole, J., Lovett, G., Findlay, S. (eds.) Comparative analysis of ecosystems. Patterns, mechanisms, and theories. Springer-Verlag, New York, p. 301-318

Ducklow, H. W., Carlson, C. A. (1992). Oceanic bacterial production. Adv. microb. Ecol. 12: 113-181

Gasol, J. M., Vaqué, D. (1993). Lack of coupling between heterotrophic nanoflagellates and bacteria: a general phenomenon across aquatic systems? Limnol. Oceanogr. 38: $657-665$

González, J. M., Sherr, E. B., Sherr, B. F. (1990). Size-selective grazing on bacteria by natural assemblages of estuarine flagellates and ciliates. Appl. environ. Microbiol. 56: 583-589

González, J. M., Suttle, C. A. (1993). Grazing by marine nanoflagellates on viruses and virus-sized particles: ingestion and digestion. Mar. Ecol. Prog. Ser. 94:1-10

Güde, $H$. (1988). Direct and indirect influences of crustacean zooplankton on bacterioplankton of Lake Constance. Hydrobiologia 159: 63-73

Güde, H. (1989). The role of grazing on bacteria in plankton succession. In: Sommer, U. (ed.) Plankton ecology. SpringerVerlag, New York, p. 337-364

Hagström, §., Azam, F., Andersson, A., Wikner, J., Rassoulzadegan, F. (1988). Microbial loop in an oligotrophic pelagic marine ecosystem: possible roles of cyanobacteria and nanoflagellates in the organic fluxes. Mar. Ecol. Prog. Ser. 49: 171-178

Hanson, J. M. Peters, R. H. (1984). Empinical prediction of crustacean zooplankton biomass and profundal macrobenthos biomass in lakes. Can. J. Fish. Aquat. Sci. 41: 439-445

Hobbie, J. E., Cole, J. J. (1984). Response of a detrital foodweb to eutrophication. Bull. mar. Sci. 35: 357-363

Jürgens, K. (1992). Is there plenty of food for bacterivorous flagellates in eutrophic waters? Arch. Hydrobiol. Beih. Ergebn. Limnol. 37: 195-205

Jürgens, K., Gasol, J. M., Massana, R., Pedrós-Alió, C. (1994). Control of heterotrophic bacteria and protozoans by Daphnia pulex in the epilimnion of Lake Cisó. Arch. Hydrobiol. 131: 55-78

Jürgens, K., Güde, H. (1991). Seasonal change in the grazing impact of phagotrophic flagellates on bacteria in Lake Constance. Mar. microb. Food Webs 5: 27-37

Kerr, S. R. (1974). Theory of size distribution in ecological communities. J. Fish. Res. Bd Can. 31: 1859-1862

Kuosa, H. (1991). Picoplanktonic algae in the northern Baltic Sea: seasonal dynamics and flagellate grazing. Mar. Ecol. Prog. Ser. 73: 269-276

Kuosa, H., Kivi, K. (1989). Bacteria and heterotrophic flagellates in the pelagic carbon cycle in the Northern Baltic 
Sea. Mar. Ecol. Prog. Ser. 53: 93-100

Kuparinen, J, Bjornsen, P. K. (1992). Bottom-up and topdown controls of the microbial food web in the Southern Ocean: experiments with manipulated microcosms. Polar Biol. 12: 189-195

Linley, E. A. S., Newell, R. C., Lucas, M. I. (1983). Quantitative relationships between phytoplankton, bacteria and heterotrophic microflagellates in shelf waters. Mar. Ecol. Prog. Ser. 12: 77-89

McManus, G. B., Fuhrman, J. A. (1990). Mesoscale and seasonal variability of heterotrophic nanoflagellate abundance in an estuarine outflow plume. Mar. Ecol. Prog. Ser. 61: $207-213$

McQueen, D. J., Post, J. R., Mills, E. L. (1986). Trophic relationships in freshwater pelagic ecosystems. Can. J. Fish. Aquat. Sci. 43: 1571-1581

Nagata, T. (1988). Seasonal abundance, grazing impacts on bacteria and vertical distribution of heterotrophic microflagellates in the South Basin of Lake Biwa. Japan. J. Limnol. 49: 167-174

Pace, M. L. (1986). An empirical analysis of zooplankton community size structure across lake trophic gradients. Limnol. Oceanogr 31.45-55

Pace, M. L., Funke, E. (1991). Regulation of planktonic microbial communities by nutrients and herbivores. Ecology 72 : 904-914

Parslow, J. S., Doucette, G. J., Taylor, F. J. R., Harrison, P. J.

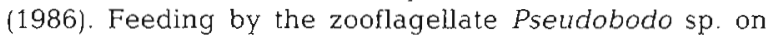
the picoplanktonic prasinomonad Micromonas pusilla. Mar. Ecol. Prog. Ser, 29: 237-246

Pick, F. R. Caron, D. A. (1987). Picoplankton and nanoplankton biomass in Lake Ontario: relative contribution of phototrophic and heterotrophic communities. Can. J. Fish Aquat. Sci. 44: 2164-2172

Pick, F. R., Hamilton, P. B. (1994). A comparison of seasonal and vertical patterns of phagotrophic flagellates in relation to bacteria and algal biomass in temperate lakes. Mar microb. Food Webs 8: in press

Rassoulzadegan, F., Sheldon, R. W. (1986). Predator-prey interactions of nanozooplankton and bacteria in an oligotrophic marine environment. Limnol. Oceanogr. 31: $1010-1021$

Riemann, B. (1985). Potential importance of fish predation and zooplankton grazing on natural populations of freshwater bacteria. Appl environ. Microbiol. 50: 187-193

Roman, M. R., Ducklow, H. W., Fuhrman, J. A., Garside, C., Glibert, P. M., Malone, T. C., McManus, G. B. (1988). Production, consumption and nutrient cycling in a laboratory mesocosm. Mar. Ecol. Prog. Ser. 42: 39-52

Sanders, R. W., Caron, D. A., Berninger, U.-G. (1992). Relationships between bacteria and heterotrophic nanoplankton in marine and fresh waters: an inter-ecosystem comparison. Mar. Ecol. Prog. Ser. 86: 1-14

Sanders, R. W., Porter, K. G., Bennett, S. J., DeBiase, A. E. (1989). Seasonal patterns of bacterivory by flagellates, ciliates, rotifers, and cladocerans in a freshwater planktonic community. Limnol Oceanogr. 34: 673-687

Sherr, B. F., Sherr, E. B., Hopkinson, C. S. (1988). Trophic interactions within pelagic microbial communities: indications of feedback regulation of carbon. flow. Hydrobiologia 159: $19-26$

Sherr, B. F., Sherr, E. B., McDaniel, J (1992). Effect of protistan grazing on the frequency of dividing cells in bacterioplankton assemblages. Appl. environ. Microbiol. 58 $2381-2385$

Sherr, B. F., Sherr, E. B., Newell, S. Y (1984). Abundance and productivity of heterorrophic nanoplankton in Georgia coastal waters. J. Plankton Res. 6: 195-202

Sherr, E. B. (1988). Direct use of high molecular weight polysaccharide by heterotrophic flagellates. Nature 335 : $348-351$

Sherr, E. B., Sherr, B. F. (1992). Trophic roles of pelagic protists: phagotrophic flagellates as herbivores. Arch. Hydrobiol. Beih. Ergebn. Limnol. 37: 165-172

Sieburth, J. McN., Davis, P. G. (1982). The role of heterotrophic nanoplankton in the grazing and nurturing of planktonic bacteria in the Sargasso and Caribbean Seas. Annls Inst. océanogr. Paris 58: 285-296

Simek, K., Chrzanowski, T H. (1992). Direct and indirect evidence of size-selective grazing on pelagic bacteria by freshwater nanoflagellates. Appl. environ. Microbiol. 58: $3715-3720$

Simek, K., Macek, M., Seda, J., Vyhnálek, V. (1990). Possible food chain relationships between bacterioplankton, protozoans, and cladocerans in a reservoir. Int. Rev. ges. Hydrobiol. 75: 583-596

Thingstad, T F., Heldal, M., Bratbak, G., Dundas, I. (1993), Are viruses important partners in pelagic food webs? Trends Ecol. Evol. 8: 209-213

Tranvik, L. J., Sherr, E. B., Sherr, B. F. (1993). Uptake and utilization of 'colloidal DOM' by heterotrophic flagellates in seawater. Mar. Ecol. Prog. Ser. 92: 301-309

Tzaras, A., Pick, F. R. (1994). The relationship between bacterial and heterotrophic flagellate abundance in temperate lakes. Mar. microb. Food Webs 8: in press

van Duyl, F. C., Bak, R. P. M., Kop, A. J., Nieuwland, G. (1990). Bacteria, auto- and heterotrophic nanoflagellates and their relations in mixed, frontal and stratified waters of the North Sea. Neth. J. Sea Res. 26: 97-109

Vaqué, D., Gasol, J. M., Marrasé, C. (1994). Grazing rates on bacteria: the significance of methodology and ecological factors. Mar. Ecol. Prog. Ser. 109: 263-274

Vaqué, D., Pace, M. L. (1992). Grazing on bacteria by flagellates and cladocerans in lakes of contrasting food-web structure. J. Plankton Res. 14: 307-321

Watanabe, Y. (1992). Effects of thermal stratification on trophic linkages among plankton communities in eutrophic lakes. Arch. Hydrobiol. Beih. Ergebn. Limnol. 35: 1-12

Weinbauer, M. G., Fuks, D., Peduzzi, P. (1993). Distribution of viruses and dissolved DNA along a coastal trophic gradient in the northern Adriatic Sea. Appl. environ. Microbiol. 59: 4074-4082

Weisse, T. (1989). The microbial loop in the Red Sea: dynamics of pelagic bacteria and heterotrophic nanoflagellates. Mar. Ecol. Prog. Ser. 55: 241-250

Weisse, T (1991). The annual cycle of heterotrophic freshwater nanoflagellates: role of bottom-up versus top-down control. J. Plankton Res. 13: 167-185

Weisse, T., Scheffel-Möser, U. (1991). Uncoupling the microbial loop: growth and grazing loss rates of bacteria and heterotrophic nanoflagellates in the North Atlantic. Mar. Ecol. Prog. Ser. 71: 195-205

White, P. A., Kalff, J., Rasmussen, J. B., Gasol, J. M. (1991). The effect of temperature and algal biomass on bacterial production and specific growth rate in freshwater and marine habitats. Microb. Ecol. 21: 99-118

Wikner, J., Hagström, A. (1988). Evidence for a tightly coupled nanoplanktonic predator-prey link regulating the bacterivores in the marine environment. Mar. Ecol. Prog. Ser. 50: 137-145

Wright, R. R. (1988). Methods for evaluating the interaction of substrate and grazing as factors controlling planktonic bacteria. Arch. Hydrobiol. Beih. Ergebn. Limnol. 31: $229-242$ 